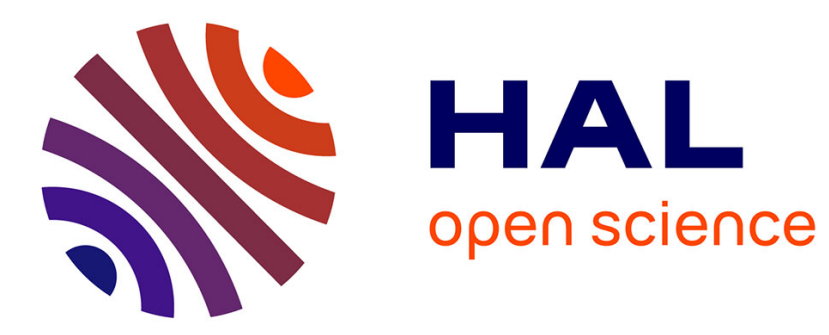

\title{
Les forêts publiques
}

- [.]revue Forestière Française, Rédaction

\section{- To cite this version:}

- [.]revue Forestière Française, Rédaction. Les forêts publiques. 1979, pp.120-121. 10.4267/2042/21317. hal-03534820

\section{HAL Id: hal-03534820 \\ https://hal.science/hal-03534820}

Submitted on 19 Jan 2022

HAL is a multi-disciplinary open access archive for the deposit and dissemination of scientific research documents, whether they are published or not. The documents may come from teaching and research institutions in France or abroad, or from public or private research centers.
L'archive ouverte pluridisciplinaire HAL, est destinée au dépôt et à la diffusion de documents scientifiques de niveau recherche, publiés ou non, émanant des établissements d'enseignement et de recherche français ou étrangers, des laboratoires publics ou privés. 


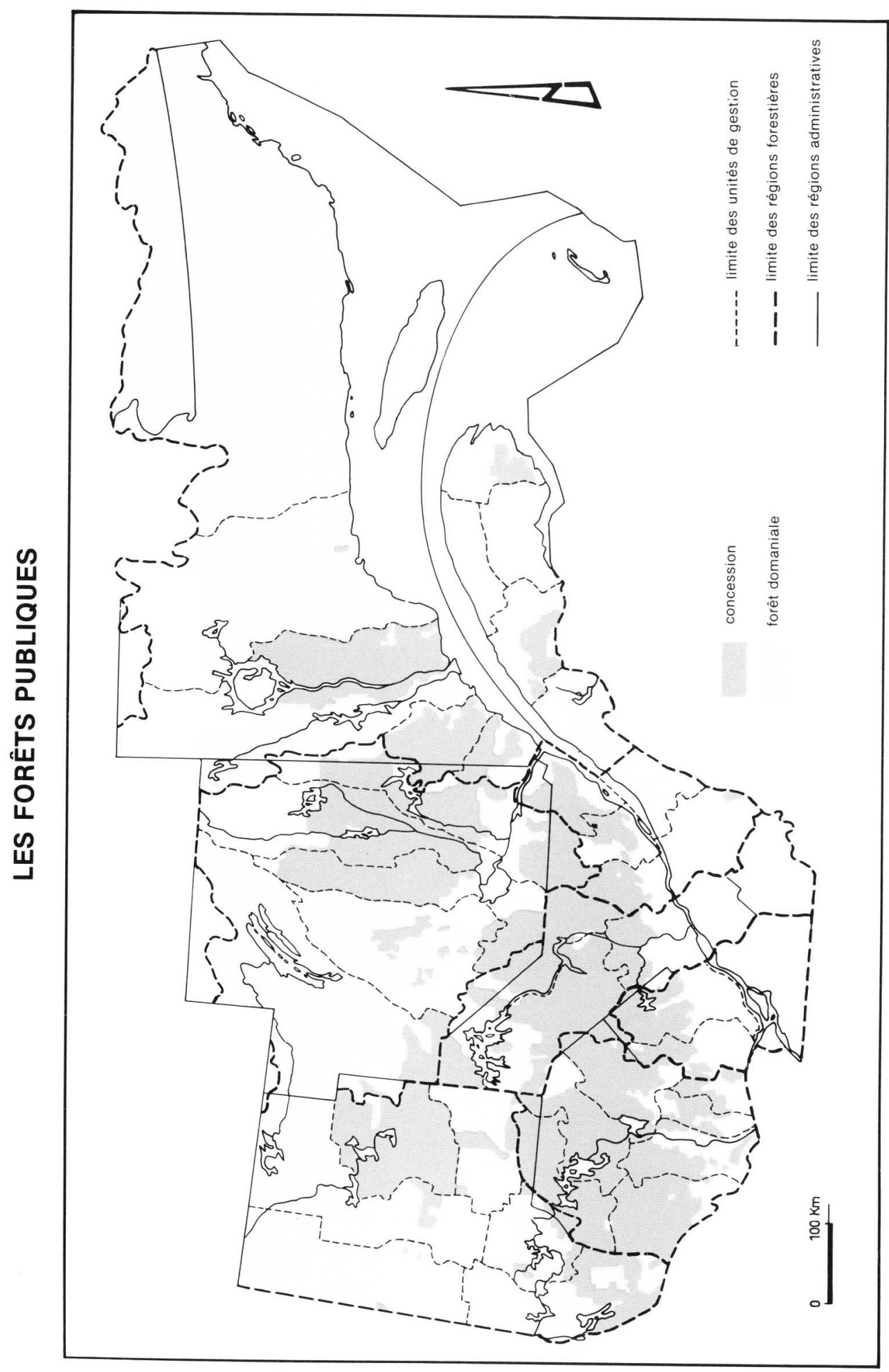




\section{Les forêts publiques du Québec}

Avant la série d'articles et points de vue sur les forêts publiques au Québec, il est nécessaire de présenter brièvement celles-ci. Ce texte a été réalisé à partir des éléments placés en introduction par les différents auteurs, évitant ainsi des répétitions.

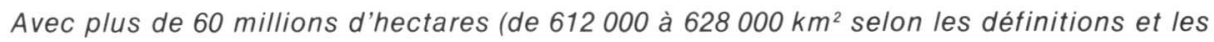
auteurs), la forêt publique constitue près de $90 \%$ de la superficie forestière totale.

Située au sud du 52e parallèle, il n'y aurait cependant que 42 à 45 millions d'hectares de forêt classée commerciale, c'est-à-dire dont les peuplements sont considérés comme exploitables.

Dans cette catégorie, 18 millions d'hectares étaient encore, début 1978, sous le régime des concessions forestières tandis que plus de 20 millions étaient forêts domaniales.

La possibilité annuelle de coupe y est d'environ 40 millions de mètres cubes par an dont $90 \%$ en résineux.

C'est la principale source d'approvisionnement de nombreuses usines et plus de 200000 foyers en tirent leur revenu principal.

On estime que la forêt publique supporte $10 \%$ des emplois et contribue pour $15 \%$ au revenu national brut. C'est dire l'importance capitale qu'elle présente pour la vie économique et sociale du Québec. 